\title{
二重反転形軸流ポンプの動翼列間圧カ干渉に関する研究
}

\section{Experimental study on blade rows interaction in contra-rotating axial flow pump}

\author{
学 吉村 浩晃（九大院） $\bigcirc$ 曹 琳琳（九大院） 本田 浩範（九大院） \\ 正 渡邊 聡（九大） 正 古川 明徳（大分高専）
}

\begin{abstract}
Hiroaki YOSHIMURA, Graduate School of Engineering, Kyushu University, Motooka 744, Nishi-ku, Fukuoka Linlin CAO, Graduate School of Engineering, Kyushu University, Motooka 744, Nishi-ku, Fukuoka Hironori HONDA, Graduate School of Engineering, Kyushu University, Motooka 744, Nishi-ku, Fukuoka Satoshi WATANABE, Department of Mechanical Engineering, Kyushu University, Motooka 744, Nishi-ku, Fukuoka Akinori FURUKAWA, Oita National College of Technology, 1666 Maki, Oita
\end{abstract}

Key Words: Axial flow pump, Contra-rotating rotors, Blade rows interaction

\section{1. 諸言}

近年，ターボ機械の小型高速化が求められており，ター ボ形ポンプにおいては更なる高比速度化による揚水性能お よび吸込み性能の低下が懸念される，そこで，著者らの研 究グループではその対策として軸流ポンプへの二重反転形 翼車の採用を提案し，その実用性を調査してきた ${ }^{(1)}$ 。二重 反転形翼車は，前段動翼とそれとは逆方向に回転する後段 動翼の双方で流体にエネルギーを直接伝達することにより 翼車 1 段当たりの負荷を低減し，ポンプの小型化に有効で ある ${ }^{(2)}$ 。一方で，その作動原理上，前後段動翼間での複雑 な翼列間干渉および部分流量域おける揚程の右上がり特性 に起因する不安定現象の発生が懸念される。そこで本研究 では，ケーシング壁面静圧計測により翼列間干渉および揚 程の右上がり不安定性について実験的に調査を行う。

\section{2. 実験装置および実験方法}

Fig.1 に実験装置の試験部断面図を示す. ポンプの設計流 量は $Q_{d}=70 \mathrm{~L} / \mathrm{s}$, 設計揚程は $H_{d}=4.0 \mathrm{~m}$ である。軸系は内外 の 2 軸構成であり, 前後段翼車はそれぞれ独立した電動機 により駆動される. 翼根元径, 先端径はそれぞれ $100 \mathrm{~mm}$, $198 \mathrm{~mm}$ であり，翼端すき間は $1 \mathrm{~mm}$ である。また，翼枚数 は前段動翼が 4 枚，後段動翼が 5 枚である。本研究で用い た翼車（以下，RR3） はその設計回転数が $N_{f}=1311 \mathrm{~min}^{-1}$, $N_{r}=1123 \mathrm{~min}^{-1}$ (添え字 $f$ は前段動翼, $r$ は後段動翼をそれぞ れ表す）で，後段動翼が前段動翼より低速，すなわち低負 荷となっている。これは過去の研究により得られた翼設計 に関する知見を反映して製作されたものであり (3)，性能試 験の結果から，設計通り後段 (図中 $\nabla$ ) が前段 (図中 $\triangle$ )

より低揚程となることが確認されるとともに， $Q=28 \mathrm{~L} / \mathrm{s}$ 以 下の低流量域において右上がり特性が現れることが分かっ

た（Fig.2）。詳細は文献(3)を参照されたい.

壁面静圧は Fig.3 に示す静止系での測定点において歪み ゲージ式圧力変換器により計測する．測定点数は前後段動 翼の軸方向にそれぞれ $8 \mathrm{Ch}$ (図中○が前段部, ○が後段部) の計 $16 \mathrm{Ch}$ である. 計測におけるサンプリング周波数は, 前段動翼が $2.5^{\circ}$ 回転する時間に対応する $3.15 \mathrm{kHz}$ (サンプ リング周期 $318 \mu \mathrm{s}$ ）とする。 また，データ取得点数は測定 点 $1 \mathrm{Ch}$ 当たり 8192 点である. 電圧[V]で得られた静圧デー タをへッド $[\mathrm{m}]$ に変換した後に FFT 解析を行い，揚程の変 動量 $\Delta H$ の周波数特性を得る.

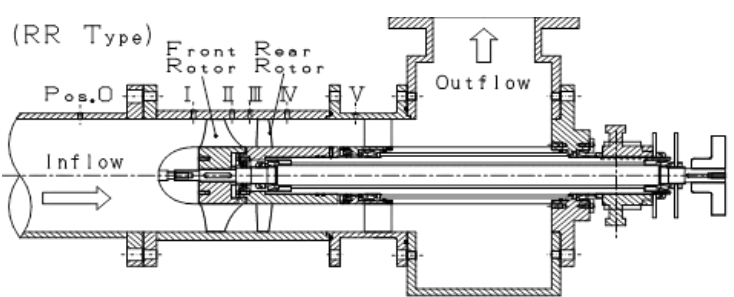

Fig.1 Schematic view of test contra-rotating pump

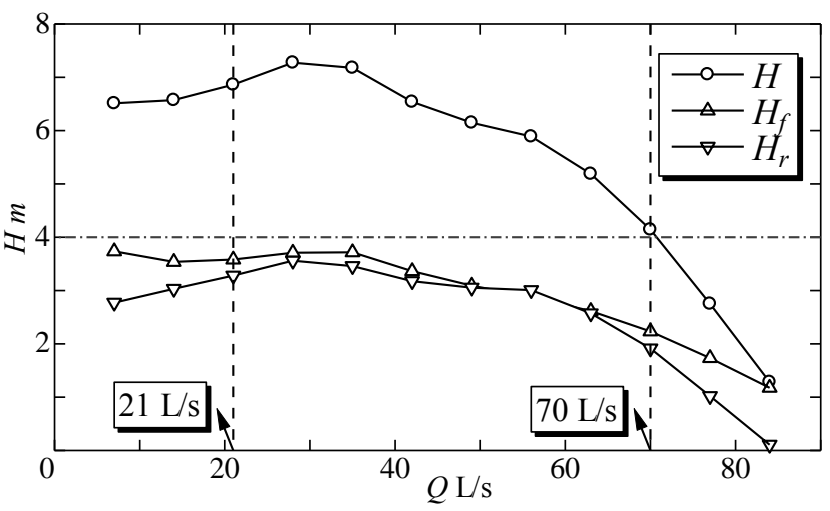

Fig.2 Pump characteristic on head

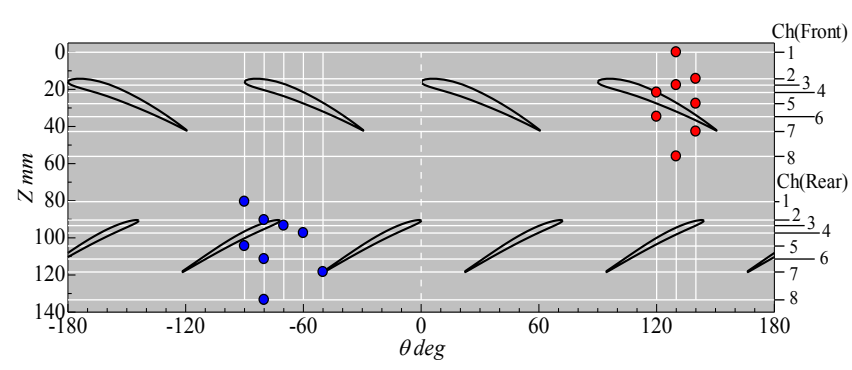

Fig.3 Axial positions of pressure measuring points 3. 実験結果および考察

\section{1 翼通過による圧力変動}

Fig.4 に設計流量 $Q=70 \mathrm{~L} / \mathrm{s}$ における後段入口（Ch1）での壁 面静圧変動の FFT 解析結果を示す. 横軸は周波数 $[\mathrm{Hz}]$ を, 縦軸は変動の強さであるパワースペクトル[m]をそれぞれ 表す. 図から, 93.7Hz において後段動翼の翼通過周波数 (BPF) による際立ったピークが存在している。また，前 段動翼の BPFによるピークも $87.5 \mathrm{~Hz}$ において確認できる. これらの圧力変動は過去の供試翼車（以下，RR2）を用い た実験においても確認されており, 特に後段動翼のBPFに よる圧力変動が前後段間流路の流れに強く干渉することが 指摘された ${ }^{(4)}$. RR2 の設計回転数が $N_{f}=N_{r}=1225 \mathrm{~min}^{-1}$ であ り，RR3 と比べて後段動翼が高負荷であることから，この 
後段動翼からの干渉は RR3 では低減されることが期待さ れ, 実際 Fig.5 に示寸圧力変動の軸方向分布から， RR3 に おける後段 BPF 成分（図中青破線）の前段動翼への影響が RR2のそれ（図中赤破線）より明らかに低減されているの が確認できる。

\section{2 回転圧力場による圧力変動}

Fig.4 において BPF 成分以外にも変動のピークが確認で き，このようなピークの存在要因の一つとして翼列間干渉 による回転圧力場の発生が考えられる。久保田ら (5) が動 静翼干渉について導出した, 回転圧力場の直径節数 $m$ およ び回転周波数 $f$ の決定法を二重反転形翼車の場合に適用す ることにより，回転圧力場の波数および周波数に関する次 式が得られる。

$$
\begin{gathered}
n R+k F=m \cdot \cdots(1) \\
f=n R f_{r}+k F f_{f} \cdot \cdots(2)
\end{gathered}
$$

ここで， $R, F$ は後段動翼および前段動翼の翼枚数， $n, k$ は各 動翼による励振次数， $f_{r}, f_{f}$ は各動翼の回転周波数をそれぞ れ表す. Fig.4 において見られた圧力変動のピーク周波数 と式(2) から求まる周波数を比較すると, $181.9 \mathrm{~Hz}, 268.3 \mathrm{~Hz}$,

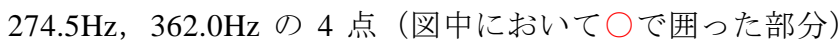
において理論值と実験值が一致しており，本研究に用いた 供試ポンプにおいてはこれらの周波数において実際に回転 圧力場が発生しているものと考えられる.

\section{3 揚程曲線の右上がり領域における圧力変動}

Fig.6に部分流量域の 1 例として $Q=21 \mathrm{~L} / \mathrm{s}$ における後段入 口の圧力変動の FFT 解析結果を示す. 各軸は Fig.3 と同様 である. $Q=70 \mathrm{~L} / \mathrm{s}$ と比較して複雑な変動様相を取っており, 変動量自体も大きくなっていることが分かる．不安定現象 による振動は一般的に数 $\mathrm{Hz}$ 数十 $\mathrm{Hz}$ 程度の低周波数で発 生し, 特に旋回失速のような回転を伴う現象では複数のセ ルを持つことが一般的に知られている。よって, 直径節を セルに置き換えれば，前節で述べた回転圧力場と同様に FFT 解析結果からポンプ内部に発生している不安定現象を 捉えることができる予想されるが, Fig.6 中においては不安 定現象か特定できるような特徵的な変動ピーク值は発見さ れなかった. Fig.7 には全流量域（ $Q=7 \sim 77 \mathrm{~L} / \mathrm{s} ）$ における圧 力変動のパワースペクトルを等高線表示したものを示す. 図から，流量（縦軸）にして 7〜 42L/s，周波数（横軸）に して $0 \sim 120 \mathrm{~Hz}$ の広い範囲において強い圧力変動が見られ るが，このような分布が現れる原因は分かっていない.

\section{4. 結言}

二重反転形軸流ポンプにおける翼列ケーシング壁面での 瞬時静圧計測を行い, 次の結論を得た。

1) 後段動翼の BPF 圧力変動は動翼間流路に強く干渉を 及ぼすが，低速化に伴う翼負荷の減少によりその効果 は弱くなることが確認された。

2 ）動翼列間干渉による回転圧力場の発生により複数の 周波数での圧力変動が確認された。

3 ）部分流量域においては, 特定の不安定現象は見られな かったが, 広い周波数領域において圧力変動が増加し た.

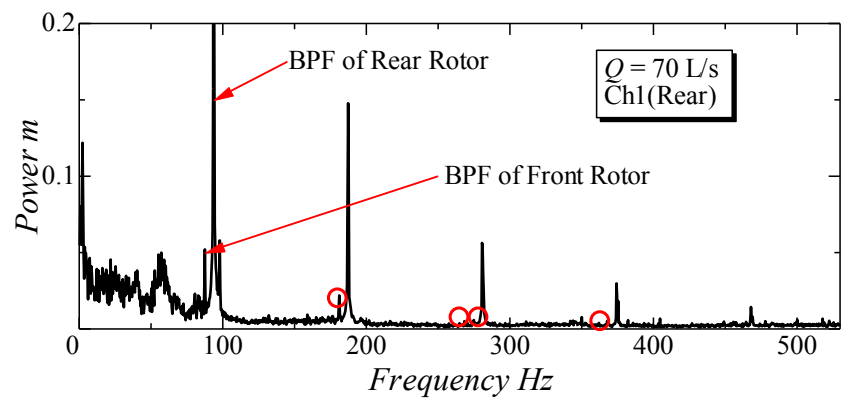

Fig.3 FFT analysis of pressure fluctuation $(Q=70 \mathrm{~L} / \mathrm{s}$, Inlet of rear rotor $)$

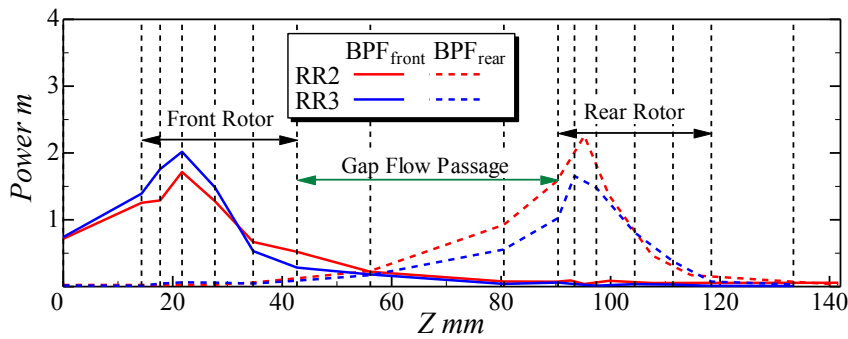

Fig.4 Axial distribution of BPF component

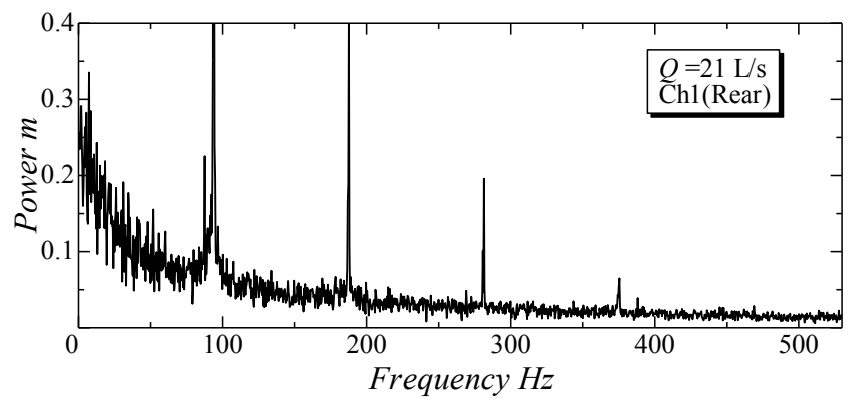

Fig.5 FFT analysis of pressure fluctuation $(Q=21 \mathrm{~L} / \mathrm{s}$, Inlet of rear rotor $)$

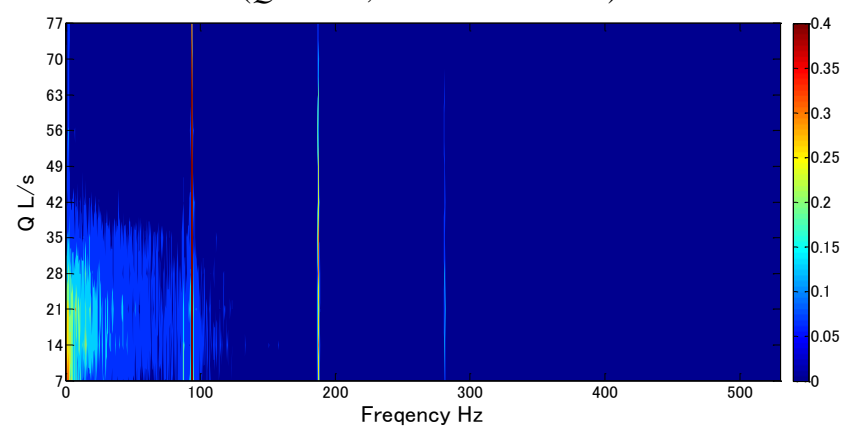

Fig.6 Contour map of pressure fluctuation

\section{参考文献}

1) 古川明徳・ほか 4 名，二重反転形軸流ポンプに関する 実験的基礎研究，機論，67-657，B(2001)， 1184-1190.

2) 古川明徳・渡邊 聡，二重反転形軸流ポンプ，ターボ機 械, 34-7 (2006), 339-403.

3) L.Cao, ほか 3 名, Low Speed Design of Rear Rotor in Contra-Rotating Axial Flow Pump, Int.J. Fluid machinery and systems, 6-2 (2013), pp.105-112.

4) 古川明徳・ほか 4 名, 二重反転形軸流ポンプのケーシ ング壁面静圧計測と翼列間干涉, 機論, 71-711, B(2005), 2710-2716.

5) 久保田裕二・ほか 4 名, 静止側の分布励振源による羽 根付回転円板の振動，機論，49-439，C(1983)，307-313 